\title{
Effect of Inoculum Load on Disease Initiation, Threshold Point and Population Build Up of Post Harvest Pathogen (Penicillium islandicum Sopp.) of Indian Gooseberry (Emblica officinalis Goerth)
}

\author{
A. K. Saini, R. S. Chauhan*, Ashwani Kumar, Narender Singh and Satish Kumar \\ Chaudhary Charan Singh Haryana Agricultural University, Hisar, Haryana-125 004, India \\ *Corresponding author
}

\section{A B S T R A C T}

Keywords

Penicillium

islandicum,

Inoculum load,

Disease initiation,

Threshold point

Article Info

Accepted:

20 August 2019

Available Online:

10 September 2019
Studies were undertaken to find out the effect of inoculum load of post harvest pathogen (Penicillium islandicum) on disease initiation, threshold point and population build up of blue mould rot in Indian gooseberry. Inoculations were made on the fruits of Indian gooseberry at five concentrations $(10,50,100,200$ and 500 spores $/ \mathrm{ml}$.). The disease initiation commenced after 54 hrs. of inoculation with inoculum load of 500 spores/ml followed by 200 spores/ml where the initiation of disease was observed after $72 \mathrm{hrs}$. At lower spore load (10 spores $/ \mathrm{ml})$, there was no disease initiation even after 108 hrs of inoculation. Minimum number of spores required to initiate infection after $102 \mathrm{hrs}$ was $50 \mathrm{spores} / \mathrm{ml}$ which can be considered as the threshold point. Maximum population build up (2 $\mathrm{x} 10^{6}$ and $2 \times 10^{8}$ ) of the pathogen occurred at 500 spores $/ \mathrm{ml}$ after 5 and 10 days of inoculation, respectively.

\section{Introduction}

Aonla or Indian gooseberry (Emblica officinalis Goerth. Syn. Phyllanthus emblica L.) belongs to family Euphorbiaceae order Euphorbiales is one of the most important indigenous fruit of Indian sub continent. It has been cultivated in India since time immemorial. It is grown in tropical and subtropical parts of India, China, Indonesia and the Malay Peninsula (Golechha et al., 2012 and Srivasuki, 2012). In India, nearly 20-
35 per cent of perishables fruits and vegetables are lost due to post harvest diseases (Rawal and Saxena, 2005). Among post harvest diseases of aonla, fruit rot caused by Penicillium islandicum Sopp. is the most important as it affects the fruit quality and quantity in relation to the market value. The open wounds, created during harvesting, handling and packaging are the major sites of invasion by post harvest wound pathogens. The major loss due to blue mould rot in aonla takes place from transit to the market. The 
fruits falling to the ground also succumb to infection. The earliest symptoms of infection due to Penicillium islandicum is seen as water soaked lesion on the fruit surface which enlarges in size followed by development of pin head size colonies of golden yellow colour. The older colonies turn olive green.

In a study, it was found that 108 conidia $\mathrm{ml}^{-1}$ of A. alternata in tomato resulted in 93.4 per cent infection recorded after 7 days of incubation meaning there by that 108 conidia $\mathrm{ml}^{-1}$ could serve as the inoculum potential of A. alternata (Verma, 2004). Yousefi and Hagian Shahri (2009) conducted pathogenicity tests by inoculating slightly wounded plant tissue with conidial suspension adjusted to $1.5 \times 10^{4}$ conidia $\mathrm{ml}^{-1}$ of Alternaria alternata using a haemocytometer that was capable of causing infection within 2-4 days. Alternaria isolates was capable of causing infection on citrus leaves from suspension of conidia (105 conidia $/ \mathrm{ml}$ ) prepared from 5-7 days old PDA cultivated isolates (Kakvan et al., 2012).

Barring a few reports about its occurrence, hence, comprehensive studies have not been under taken regarding this pathogen of aonla fruit, taking into consideration the medicinal value of the fruit, economic losses by the disease and inadequate information, the investigation was carried out to find out the effect of inoculum load of post harvest pathogen (Penicillium islandicum) on disease initiation, threshold point and population build up of blue mould rot in Indian gooseberry.

\section{Materials and Methods}

The study on disease initiation, threshold point and population build up at optimum temperature and humidity was conducted. Spore suspension, from seven days cultures, prepared in distilled and sterilized water and the initial concentration was adjusted to 1000 spores/ml with the help of haemocytometer.
Serial dilutions were made to obtain 1000 , 500, 200, 100, 50 and 10 spores/ml with sterile distilled water. Fruits were inoculated using $0.5 \mathrm{ml}$ of test spore suspension and punctures were plugged back. The injury was sealed with sterile paraffin wax and incubated at $27 \pm 1^{0} \mathrm{C}$ under aseptic conditions. Inoculated fruits were examined after every 6 hours for disease initiation and threshold point of the pathogen. Subsequent build up of population was assessed after 10 days of incubation. The diseased portion was scooped out with knife and the percentage rot was calculated. One gm of diseased tissue was homogenized in $5 \mathrm{ml}$ of water with a waring blender and the concentration of the spores was recorded with the help of haemocytometer.

\section{Results and Discussion}

\section{Effect of inoculum load on disease initiation and threshold point}

In order to study the effect of varying inoculum load on the establishment of the disease, aonla fruits were injured and inoculated with $0.5 \mathrm{ml}$ spore suspension of different concentrations ranging from 5 to 100 spores/ ml. Inoculated fruits were incubated at $27 \pm 1^{\circ} \mathrm{C}$ and observations were recorded at 6 hours interval up to 108 hours for initial appearance of visible symptoms. The data presented in Table 1 indicated that the time required for appearance of visible symptoms decreased with the increase in amount of inoculum. Concentration of 5 spores $/ \mathrm{ml}$ failed to cause infection indicating that the threshold point for the infection is more than 5 spores $/ \mathrm{ml}$. No symptoms were visible up to 84 hours with a spore load of 50 spores $/ \mathrm{ml}$ and symptoms could be noticed only after 90 hours. The disease was visualized within 48 hours when 250 spores were used. The rate of development was also faster with increased inoculum load. 
Effect of inoculum load on population build up

The inoculum load has influenced the disease development as well as the rate of multiplication of the fungus as observed from the number of spores produced from variously inoculated fruits. Perusal of data from Table 2 indicated that the number of propagules produced increased proportionately with the number of spores used for inoculating the fruits. The number of spores produced on the fruits varied from $1.9 \times 10^{5}$ to $2.1 \times 10^{8}$ for 25 to 250 spores $/ \mathrm{ml}$ inoculum.

\section{Average of four replications}

Investigations on the inoculum potential of Penicillium islandicum on aonla at optimum temperature and humidity has revealed that the time required for the establishment of infection is positively correlated with the inoculum load. The subsequent rate was also faster with the increasing amount of inoculum. This observation is in agreement with the earlier reports of Spotts and Cervantes (2001) and Luo et al., (2001). The rate of multiplication has shown positive correlation with amount of inoculum. A minimum number of 100 spores/ml was necessary for initiating the disease which indicated that threshold point for this fungus is 50 spores per inoculation. On the contrary, Noe and Starkey (1982) did not record bitter rot infection in apple at an inoculum of even $10^{3}$ conidia per $\mathrm{ml}$ which may be due to different host parasite relationship.

A minimum number of 50 spores $/ \mathrm{ml}$ was necessary for disease initiation which indicates that inoculum threshold point of this fungus to cause infection is 25 spores/inoculation. Maximum population build up of Penicillium islandicum was observed at the concentration of 500 spores $/ \mathrm{ml}$ after 5 and 10 days of inoculation on the fruits.

Table.1 Effect of inoculum load on disease initiation and threshold point of aonla blue mould rot

\begin{tabular}{|c|c|c|c|c|c|c|c|c|c|c|c|c|}
\hline \multirow{2}{*}{$\begin{array}{l}\text { Concentration } \\
\text { of spores } / \mathrm{ml}\end{array}$} & \multirow{2}{*}{$\begin{array}{l}\text { No. of } \\
\text { spores / } \\
\text { fruit } \\
(0.5 \mathrm{ml})\end{array}$} & \multicolumn{11}{|c|}{ Disease initiation after hrs of inoculation } \\
\hline & & 48 & 54 & 60 & 66 & 72 & 78 & 84 & 90 & 96 & 102 & 108 \\
\hline 10 & 5 & $-*$ & - & - & - & - & - & - & - & - & - & - \\
\hline 50 & 25 & - & - & - & - & - & - & - & - & - & \pm & + \\
\hline 100 & 50 & - & - & - & - & - & - & \pm & + & ++ & +++ & ++++ \\
\hline 200 & 100 & - & - & - & \pm & + & ++ & +++ & ++++ & & $\begin{array}{l}\text { of in } \\
\text { easing }\end{array}$ & ection \\
\hline \multirow[t]{7}{*}{500} & 250 & \pm & + & ++ & +++ & ++++ & Are & of in & fection & ncre: & sing & \\
\hline & - & \multicolumn{11}{|c|}{ No infection } \\
\hline & \pm & \multicolumn{11}{|c|}{ Suspected infection } \\
\hline & + & \multicolumn{11}{|c|}{ Slight infection $5 \mathrm{~mm}$ diameter } \\
\hline & ++ & \multicolumn{11}{|c|}{$10 \mathrm{~mm}$ diameter } \\
\hline & +++ & \multicolumn{11}{|c|}{$15 \mathrm{~mm}$ diameter } \\
\hline & ++++ & \multicolumn{11}{|c|}{$20 \mathrm{~mm}$ diameter } \\
\hline
\end{tabular}


Table.2 Effect of inoculum load on population build up of Penicillium islandicum causing blue mould rot in aonla

\begin{tabular}{|c|c|c|c|}
\hline $\begin{array}{c}\text { Concentration of } \\
\text { spores/ml }\end{array}$ & $\begin{array}{c}\text { No. of spores / fruit } \\
(\mathbf{0 . 5} \mathbf{~ m l})\end{array}$ & \multicolumn{2}{|c|}{ Population build up } \\
\hline $\mathbf{1 0}$ & 5 & - & After 5-Days \\
\hline $\mathbf{5 0}$ & 25 & $1.9 \times 10^{5}$ & - \\
\hline $\mathbf{1 0 0}$ & 50 & $4.8 \times 10^{5}$ & $1.1 \times 10^{7}$ \\
\hline $\mathbf{2 0 0}$ & 100 & $1.2 \times 10^{6}$ & $2.7 \times 10^{7}$ \\
\hline $\mathbf{5 0 0}$ & 250 & $1.8 \times 10^{6}$ & $1.5 \times 10^{8}$ \\
\hline
\end{tabular}

\section{References}

Golechha, M., Sarangal, V., Ojha, S., Bhatia, J. and Arya, D.S. 2014. Anti-Inflammatory effect of Emblica officinalis in Rodent Models of Acute and Chronic inflammation: Involvement of possible mechanisms.. Journal of Environmental Biology. 33: 95100.

Kakvan, N., Zamanizadeh, H., Morid, B., Taheri, $\mathrm{H}$ and Hajmansor, S. 2012. Study on pathogenic and genetic diversity of Alternaria alternata isolated from citrus hybrids of Iran, based on RAPD-PCR technique European Journal of Experimental Biology. 2(3): 570-576

Luo, Y., Ma, Z., and Michailides, T. J. 2001. Analysis of factors affecting latent infection and sporulation of Monilinia fructicola on prune fruit. Plant Disease. 85: 999-1003.

Noe, J. P. and Starkey, T. E. 1982. Relationship of apple fruit maturity and inoculum concentration to infection by Glomerella cingulata. Plant Diseases. 66: 379-381

Rawal, R. D. and Saxena, A. K. 2005.
Management of post harvest diseases of tropical fruits with reference to India. Abstract in Second Global Conference, Plant Health-global Wealth, Nov. 25-29, Udaipur, India. pp. 133.

Spotts, R. A., and Cervantes, L. A. 2001. Disease incidence inoculum dose relationships for Botrytis cinerea and Penicillium expansum and decay of pear fruit using dry, airborne conidia. Plant Disease. 85: 755-759.

Srivasuki, K. P. 2012 Nutritional and health care benefits of Amla. Journal of Pharmacognosy. 3: 147- 151.

Verma, U. K. 2004. Ph.D thesis titled Management of postharvest diseases of tomato (Lycopersicon esculentum Mill.) with special emphasis on biological control. Botany Department, Lucknow University, Lucknow.

Yousefi, A. M. and Hagian, S. 2009. Brown spot disease of peach and apricot trees, pathogenicity and overwinter. Asian Journal of Plant Pathology. 3: 61-69.

\section{How to cite this article:}

Saini, A. K., R. S. Chauhan, Ashwani Kumar, Narender Singh and Satish Kumar 2019. Effect of Inoculum Load on Disease Initiation, Threshold Point and Population Build Up of Post Harvest Pathogen (Penicillium islandicum Sopp.) of Indian Gooseberry (Emblica officinalis Goerth). Int.J.Curr.Microbiol.App.Sci. 8(09): 2082-2085. doi: https://doi.org/10.20546/ijcmas.2019.809.239 